\title{
Sivistyksellistä syvämuokkausta - oma yhdistys kokosi voimat
}
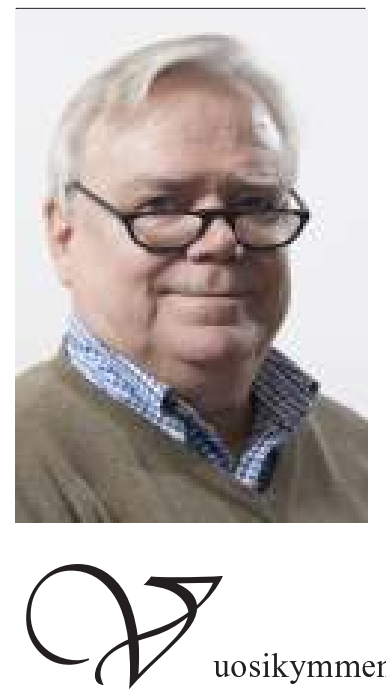

uosikymmenten ajan Kansansivistysopillisella Yhdistyksellä on sen jälkeen ollut puheenjohtajan paikalla esimies, kunnes nykyinen luotsi, professori Anja Heikkinen ryhtyi kutsumaan itseään ajan feminististen virtausten mukaisesti sukupuolineutraalisti esihenkilöksi.

Ensimmäisiksi toimihenkilöiksi vuonna 1940 valittiin varaesimieheksi kanslianeuvos Niilo Liakka sekä johtokuntaan kouluneuvos Yrjö Länsiluoto, opettaja Arvi Hautamäki ja Uudenkirkon, myöhemmin Kanneljärven kansanopiston johtaja Erkki Paavolainen.

Takana oli suuri kansallinen murhenäytelmä, Suomen talvisota. Se vahvisti entisestäänkin tarvetta korostaa yksimielisyyttä ja yhteenliittymisen merkitystä.

Kansansivistystyö oli laajentunut 1930-luvun loppupuolelle tultaessa huomattavasti. Työväenopistoja oli jo liki puolensataa ja kansanopistoja kuutisenkymmentä eri puolilla maata. Kirkon ja työväenliikkeen sivistysjärjestöt olivat toiminnassa ja kansansivistäjien koulutus oli päässyt alkuun Yhteiskunnallisessa Korkeakoulussa, jossa myös kansansivistäjiksi itsensä identifioiva kirjastoväki opiskeli.

Yhdistys katsoi keskeisimmäksi tehtäväkseen edistää kansansivistysopillista tutkimusta ja teoreettista keskustelua. Toimintamuodoiksi määritel- tiin esitelmä- ja keskustelutilaisuudet sekä julkaisutoiminta. Ensimmäisen toimintavuoden aikana esitelmätilaisuuksia järjestettiinkin runsaasti ja pari kertaa yhdistyksellä kävi kansainvälisiäkin vieraita. Sittemmin esitelmätilaisuudet rajoittuivat lähinnä vuosikokousten yhteyteen.

Yhdistys perustui henkilöjäsenille, jotka johtokunta valitsee. Akateemisten osuus oli alusta asti vahva. Ensimmäisenä toimintavuonna jäsenistä oli neljäsosa tohtoreita tai professoreita.

Tukea yhdistys sai vapaan sivistystyön järjestöiltä1 ${ }^{1}$ ja toiminnan pitkän juoksun aikana Alfred Kordelinin säätiöltä.

Kun kansansivistysopin tiedekäsityksissä tapahtui muutos ja kun sivistystyön käytännön alue alkoi laajeta aikuisten ammatillisen koulutuksen suuntaan, oppiaineen ja professuurin nimi muuttui vuonna 1965 aikuiskasvatukseksi. Yhdistys muutti nimensä viipeellä Aikuiskasvatuksen Tutkimusseuraksi vuonna 1971.

\section{Yhteistyökumppaniksi \\ Kansanvalistusseura}

Merkittävintä ja kestävintä antia tutkimusseuran toiminnassa on ollut laajaksi ja monipuoliseksi kehittynyt julkaisutoiminta. Hyvistä oppikirjoista ja muusta oppimateriaaleista oli jatkuva pula, jota 
omilla julkaisuilla pyrittiin lievittämään. Tässä yhteistyökumppaniksi tuli Kansanvalistusseura ja taloudellisiksi tukijoiksi Kordelinin säätiö ja Suomen Akatemia.

Säännöllisesti ilmestyvistä julkaisuista käynnistyi ensimmäisenä seuran vuosikirja Vapaa kansansivistystyö, joka ilmestyi ensimmäisen kerran jo vuonna 1942. Nimi muutettiin 1970-luvun alussa Vapaan sivistystyön vuosikirjaksi ja vihdoin vuonna 1995 Aikuiskasvatuksen vuosikirjaksi.

Ensimmäisten vuosikirjojen materiaaleja olivat kokousmateriaalit ja -esitelmät, kunnes 1960-luvulla kirjoja alettiin teemoittaa ${ }^{2}$. Vuosikirjat ovat olleet yliopistojen kasvatustieteiden kurssivaatimusten vakioaineistoa. Aivan kaikkina vuosina kirja ei ole ilmestynyt: seuraava suunnittelutyön alla oleva on 50:s.

Myös alan aikakauslehden julkaiseminen oli seuran hankkeissa jo varhain. Vuonna 1948 alkoi ilmestyä professori Urpo Harvan päätoimittama aikakauslehti Kansansivistys. Lehdessä julkaistiin artikkeleita, kirja-arvosteluja ja uutisia. Tärkeimmistä artikkeleista julkaistiin lopussa englanninkielinen summary. Kiinnostavana yksityiskohtana pitää mainita nimimerkki Taivaltajan pakinat, joissa tartuttiin alan tärkeimpiin ongelmiin ja herätettiin keskustelua ja ajatustenvaihtoa.

Lukija- ja kirjoittajapula johtivat kuitenkin yhdistyksen vetäytymiseen toimitustyöstä vuoden 1954 jälkeen, Kansanvalistusseura toimitti lehteä yksin vielä kolme numeroa. Ensimmäinen yritys julkaista säännöllisesti ilmestyvää tieteellisluonteista alan aikakauslehteä Suomessa oli siltä erää päättynyt.

Runsas neljännesvuosisata myöhemmin tehtiin toinen, ja nyt kestävämpi yritys tieteelliseksi aikakauslehdeksi, jälleen Kansanvalistusseuran ja Aikuiskasvatuksen Tutkimusseuran yhteistyönä. Idea newsletter-tyyppisestä tiedotuslehdestä kypsyikin tiedelehdeksi ${ }^{3}$, jolle haettiin ja saatiin Suomen Akatemian tiedelehtitukea. Neljä kertaa vuodessa ilmestyvän tiedelehden Aikuiskasvatus ensimmäinen numero ilmestyi vuonna 1981 . Tutkimusseuran täyttäessä 70 vuotta sen keskeisimmästä julkaisusta on siis ilmestynyt 30 vuosikertaa.

ATS on vaikuttanut omien julkaisujensa lisäksi myös monien oppikirjakäytäntöön tarkoitettujen teosten aikaansaamiseksi ${ }^{4}$. Tärkeä julkaisutyyppi, jossa yhdistys on ollut vaikuttamassa, on alan bibliografiat. Erityisesti aikuiskasvatuksen historiallisen tutkimuksen apuvälineinä bibliografiat ${ }^{5}$ ovat olleet korvaamattomia.

\section{Tutkijatapaamisen kohtauspaikkana}

Aikuiskasvatustutkimuksen tekijäjoukko laajeni 1980-luvulla merkittävästi, kun Tampereen yliopiston lisäksi useimmissa muissa yliopistoissa perustettiin opetus- ja tutkimusvirkoja ja käynnistettiin alan tutkimus.

Ensimmäinen kaksipäiväinen tutkijatapaaminen pidettiin elokuussa 1989 Oriveden Opistossa. Se kokosi Helsingin, Jyväskylän, Kuopion, Tampereen ja Turun yliopistojen sekä Teknillisen korkeakoulun ja Suomen Akatemian tutkijat yhteen. Sittemmin tutkijatapaaminen on järjestetty parin kolmen vuoden välein eri yliopistopaikkakunnilla Monista tutkijatapaamisista on toimitettu myös julkaisu.

\section{Kontaktit maailmalle}

Tutkimusseuran kansainväliset kontaktit ovat olleet pienimuotoisia ja satunnaisia, lähinnä johtokunnan jäsenten yliopiston laitosyhteyksien kautta syntyneitä sekä epävirallisia henkilösuhteita.

Pohjoismaisia aikuiskasvatuksen tutkijoiden konferensseja alettiin järjestää vuodesta 1990 alkaen Göteborgissa yhteistyössä Nordens folkliga akademin (NFA) kanssa. Konferenssien esitelmistä on toimitettu yhteisjulkaisu, Adult education research in Nordic countries, jonka toimituskunnassa seuralla on edustus. Viimeisin niistä on Liberty, Fraternity and Equality (2007), joka perustuu vuonna 2005 Turussa pidettyyn pohjoismaiseen konferenssiin.

European Society for Research on the Education of Adults (ESREA) perustettiin Hollannissa 1991. ATS liittyi sen jäseneksi 1994 ja sai edustajansa sen johtokuntaan. ESREA järjestää joka kolmas vuosi kansainvälisen tutkijakonferenssin. Viimeksi se oli kesäkuussa 2009 Turussa.

Tutkimusseuran jäsenet olivat luontevia kirjoittajia Kansanvalistusseuran vuosina 1964-1990 julkaisemassa, suomalaista aikuiskasvatusta esittelevässä lehdessä Adult Education in Finland. Kansanvalistusseura haki tutkimusseuran silloisen esimiehen Antti Kaupin ideasta projektirahaa Euroopan Unionilta yleiseurooppalaisen aikuiskasvatuslehden perustamiseksi. Saadun kertaluonteisen tuen turvin käynnistettiin vuonna 1996 uusi lehti Lifelong Learning in Europe (LLinE). Myöhemmin opetusministeriön rahoittaman lehden toimitus on Kansanvalistusseurassa. ATS on lehden toinen julkaisija. 
Seuralla on ollut onni saada esimiehiksi pitkäaikaisesti tehtäväänsä sitoutuneita henkilöitä: T.J. Wuorenrinne, Urpo Harva, Aulis Alanen, Jukka Tuomisto, Antti Kauppi ja Anja Heikkinen. Vaikka seuran johtokunnan nimilista on ollut varsin miesvoittoinen, on tässä tapahtunut muutos. Naisten osuus ja rooli seuran toiminnasta on nykyisellään vahva. Näin pitää ollakin: kun yliopistojen jatkotutkintojen suorittajista lähes kaikilla opintoaloilla selvästi yli puolet on naisia, näkyy heidän panoksensa myös aikuiskasvatuksen eri osa-alueilla.

\section{Rainer Aaltonen}

\section{Viitteet}

1. Vapaan sivistystyön järjestöt ovat itse köyhiä, joten ainakin viime vuosikymmeninä tuki lienee henkistä laatua.

2. Vapaan sivistystyön/ Aikuiskasvatuksen vuosirkertojen teemoista ks. wikipedia: Aikuiskasvatuksen vuosikrija.
3. Idean aikuiskasvatukselliset toimijat yhdistä västä newsletterista sai Kansanvalistusseuran silloinen pedagoginen johtaja Pentti Yrjölä. Tutkimusseuran esimiehen, apulaisprofessori Jukka Tuomiston rohkaisemana aloitetta alettiin jalostaa tieteelliseksi lehdeksi. Lehden kannattavuus rakennettiin isoille könttätilauksille, joista enin osa saatiin vapaasta sivistystyöstä, kuten Kansalais- ja työväenopistojen liitosta sekä muutamasta opintokeskuksesta. Lehden ensimmäiseksi päätoimittajaksi tuli Jukka Tuomisto ja toimitussihteeriksi Pentti Yrjölä. Toimitus oli ja on edelleen Kansanvalistusseurassa. Lehden tähänastiset päätoimittajat: http://www.aikuiskasvatus.fi/

4. Ks. tarkemmin: http://www.protsv.fi/ats/dokumentteja/muut/ats_historiikki_rainer_aaltonen.pdf

\section{Lisää bibliografioista:}

http://www.protsv.fi/ats/dokumentteja/muut/ ats_historiikki_rainer_aaltonen.pdf

\section{Aikuiskasvatusta etsimässä}

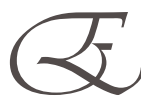
opillinen Yhdistys ja nykyinen Aikuiskasvatuksen Tutkimusseura täyttää 7. joulukuuta 70 vuotta. Siinä, missä 70 vuotta sitten oltiin huolissaan koko kansan koulutuksesta ja sivistyksestä, keskitytään nykyään työikäisten jälleenkoulutuksen ja työssäoppimisen problematiikkaan; miten saada ihmiset pysymään työelämässä pidempään ja vastaamaan radikaalisti muuttuneisiin työelämän vaateisiin. Miten saada työntekijän koko potentiaali käyttöön ja kuinka tehdä se mahdollisimman kustannustehokkaasti. Tehokkuusajattelu on ymmärrettävää yritysmaailmassa, mutta jotta tästä trendistä ei tulisi ainoa aikuiskasvatuksen suuntaa ja tutkimusta määrittävä kompassi

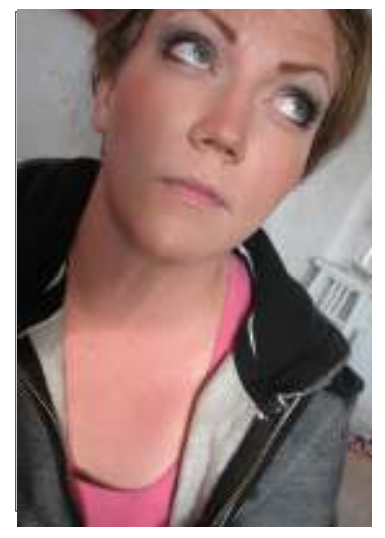

olisi mielestäni hyvä pysähtyä miettimään, mitä aikuiskasvatuksen olisi oikeasti hyvä pitää sisällään ja mitkä elementit tulisi asettaa kriittisen tarkastelun alle.

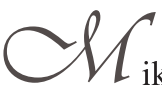
vatuksesta oman tieteensä ja miksi sitä halutaan opiskella? Lapin yliopiston tuoreen opinto-oppaan selaaminen ja vertailu yleisen kasvatustieteen kanssa ei tuota yllä mainittuun kysymykseen kovin tyhjentävää vastausta. Aikuiskasvatus ei poikkea mainittavasti yleisen kasvatustieteen opinto-ohjelmasta. Itse asiassa, aikuiskasvatus ei profiloidu juuri mitenkään jos opinto-oppaaseen on uskominen. Aikuiskas- 